\title{
Employer brand attractiveness: the effect of demographic variables on career goals
}

\author{
Niken Lulanti Rahayu', Gugup Kismono ${ }^{2 *}$ \\ ${ }^{1,2}$ Faculty of Economics and Business, Universitas Gadjah Mada, Yogyakarta, Indonesia \\ *Corresponding author: gugup_kismono@ugm.ac.id
}

Article Info
Article history:
Received : 14 December 2020
Accepted : 3 February 2021
Published : 1 July 2021

JEL Classification Code: M51, M37, M12

Author's email: nrahayu.ms@gmail.com

DOI: 10.20885/jsb.vol25.iss2.art1

\begin{abstract}
Purpose: This research aimed to observe the differences between respondents' characteristics based on their career goals as part of employer brand, and to identify effective employer branding. It was important since many businesses failed to attract the best talent due to limited knowledge on organizational attractiveness and employer branding strategy.
\end{abstract}

Design/methodology/approach: The data were collected through self-administered questionnaire. There were 12 items used to represent career goals attributes in employer branding. The data was ordered based on the characteristics' relative importance and assigned points accordingly (the first rank is scored the highest $=6$ ) and analyzed using a K-related samples test and weighted-mean average computation with ANOVA tables. K-independent samples and a One-Way ANOVA test to identify the differences of career goals preferences.

Findings: Results showed that there were various significant different across respondents' characteristics such as gender, marital status, academic achievement, work experience, and economic background. The differences between each group for the most and the least important career goals can still be observed. The findings for career goals items are generally consistent with the known theories of organizational attraction.

Research limitation/implications: The data were collected from business school students. It is limited in that it may not have captured the reflections of potential employees groups in Indonesia whose characteristics combinations of experience and attitudes toward employer brand differed from the sample used. Applying these research findings should be done meticulously.

Practical implications: This research offered an interesting insight on the relations of employer brand's attractiveness dimensions, career goals, and individual differences. Based on this research findings, organizations may consider emphasizing on the attributes that are attractive to highachievers or to one specific gender.

Originality/value: This research contributed to identifying how respondents perceive the dimensions ranking of employer brand attractiveness and analyzing the detail characteristics attractiveness (career goals) based on demographic variables.

Keywords: Employer branding, career goals, gender, marital status, academic achievement, work experience, economic background.

\section{Introduction}

In rapidly changing business environment, many organizations have come to realize that their employees' talents and skills are critical for their success. A well-managed human resource is now 
seen as one of the competitive advantages that can give an edge for organizations compared to their rivals (Becker \& Huselid, 2006). Thus, it is of great importance that organizations are capable to retain and attain highly-qualified talents (Vijayalakshmi \& Uthayasuriyan, 2015).

In Indonesia, many job seekers might present a low level of competencies in a particular area. Users criticized the candidates for being lack of leadership and communication skills (Kabarjatim, 2018). Additionally, companies learned that many applicants show their low level of self-confidence and sense of responsibility. Unfortunately, the young generation that seeks the jobs requires to instantly assuming good positions with satisfactory benefits (Barron et al., 2014; Ranstad, 2019; Twenge et al., 2010; Utomo, 2019).

Considering the quality of many applicants, the increasing number of job seekers and their quality may create a problem for organizations to attain highly-qualified employees. Furthermore, in many countries, it has been observed that previously employees changed their jobs only twice or thrice in their entire career. However, nowadays, the growing tendency to switch jobs is at an escalating pace. Consequently, the battle for getting the best employees from the job market has resulted in fierce competition among Human Resource (HR) professionals (Gaddam, 2008; Mercer, 2020; Prahadi, 2016).

As attracting the best talents is getting more challenging not only in the Western countries where many studies have been done but also in many developing countries such as in Asia, a research on employer branding in Indonesia may contribute to the enrichment of employer branding and a better understanding of the importance of this field in the Eastern countries. With more than 199.38 million prospective employees (Badan Pusat Statistik, 2020), companies in Indonesia have a very serious challenge to attract high-quality candidates who are fit with the companies (BCG, 2013; Mercer, 2020; Tong \& Waltermann, 2013). Well-managed employer brands may serve as pre-screening tools as they address the expected mismatch between the companies and the job seekers, particularly mismatch between the companies and the candidates who have a good chance to be promoted for strategic positions.

This article seeks to identify several important issues. First, identifying how respondents perceive the dimensions ranking of employer brand attractiveness. Second, analyzing the detailed characteristics of attractiveness (career goals) based on gender, marital status, academic achievement, working experience, and economic background among the Indonesian graduate business school students. Thus, this study aims to describe the detailed characteristics of the attractiveness of employer brand based on the different characteristics of the Indonesian graduate students.

\section{Literature Review}

\section{Employer Branding}

Employer branding is the development and communication of an organization's culture as an employer in the marketplace. It conveys the value propositions of the company along with encouragement to embrace and share goals for success (Mandhanya \& Shah, 2010). It impacts organization culture and organization identity that in turn contribute to employer brand loyalty (Backhaus \& Tikoo, 2004). Employer branding is now perceived to be the key for recruitment.

The concept of employer branding is originated in the United Kingdom. Barrow and Mosley (2005) further developed the concept by arguing that in reality an organization's ultimate success is determined by recruiting, engaging, and retaining good people. They explored and researched practices in successful organizations and discovered the strong presence of the employer branding concept.

Essentially, employer branding is the articulation of a company's brand positioning within its recruiting and human resources marketplace (Florea, 2011). It involves two basic marketing strategies: fine-tuning the company's position so that it is seen and experienced in a manner that draws the most qualified people and relaying the company's operating principles so that candidates and employees understand and are invested in them (Johnson \& Roberts, 2006). Mandhaya and Shah (2010) explain several types of employer branding: employer branding, recruitment branding, 
and internal and external branding. Employer branding provides a snapshot of the company; it promotes and profiles the company to potential candidates and should best describe what it feels like to work for the organization. Recruitment branding advertises positions that are vacant in companies and explains the process for application. Internal and external branding are the different approaches to building an employer brand. They focus on creating visibility in the target talent markets through a multifaceted approach including a well-designed website, compensation practice, and career opportunities. Aldousari et al. (2017) and Theurer (2018) argue that effective branding will help not only to attract candidates and raise their profile as an employer of choice but also to improve companies' performance and competitiveness. The Society for Human Resources Management or SHRM (Maurer, 2017) highlights that HR uses the employer brand for several important reasons including achieving optimum person-organization fit, positive outcomes for recruiting, and retaining talent. At its most effective, a well-designed employer brand is a longterm strategy with a transparent message that promotes the organization as an ideal employer.

The key to a successful employer brand is to ensure that expectations are fully aligned with the realities of working for the organization (Maurer, 2017). It should be an ongoing, systematic process that necessitates continuous investment as well as a logical approach to reach its main goal: to have a strong appeal on current and future ideal-talented employees in a sustainable manner (Daniel \& José, 2010). Thus, a powerful employer brand has the capacity both to attract and retain talent while also represent quality to its customers (Ilyas et al., 2019). Forward-thinking companies re-engineer the processes of strategic staffing, talent assessment and replacement planning, talent development, and performance management to create one holistic system that drives the business and integrate a number of businesses, organizational and human resource processes Darius Gholamzadeh and Jalali (2013). Thus, a strong employer brand attracts more qualified applicants (Collins \& Stevens, 2002) and shapes their expectations about their employment (Lievens \& Highhouse, 2003). Furthermore, Johnson and Roberts (2006), and Theurer et al. (2018) also argue that ensuring strong branding initiatives can be the key to a company's competitiveness. This is because employer branding optimizes recruitment and encourages employee productivity, loyalty, and retention. Successful implementation of employer branding leads to business growth. Thus, as expected, the awareness towards the importance of employer branding is constantly increasing (Gaddam, 2008) and companies are allocating more funds to their employer brands (Davies, 2008). However, to be more effective, organizations should understand the detailed information regarding attributes that are attracted to potential candidates. The detail attributes are derived from dimensions of employer brand: items in employer brand dimensions or career goals that are attracted to a specific group of people.

\section{Different Perceptions on Career Goals}

Employer branding strategy will not be effective unless career goals, that is a detailed orientation and preference, of the talented candidate is identified. A career goal is an integral part of dimensions in employer brand. Understanding specific career goal is crucial in developing a strategy to attract suitable talented candidates, i.e. graduate students. An organization needs to understand the preference of talented candidates on specific career goals whether it is very unimportant, unimportant, somewhat unimportant, somewhat important, important, and very important.

Individual differences are known to play a role in shaping career-and-employment-related decisions among graduate students (Caligiuri et al., 2010). Gowan (2004) suggests that differences in cultural values will influence the way applicants perceive the different dimensions of a prospective employer. While a positive employer reputation can increase attraction to the organization, there may be differences in the importance attached to it based on one's cultural values, individual needs, or both (Biswas \& Suar, 2013). Thus, in relation to the HR strategy, understanding differences and positioning the employer brand accordingly is critical for personjob and person-organization fit (Ghielen et al., 2020; Sekiguchi, 2004; Tanwar \& Kumar, 2019).

First, the relative importance or preference of the job selection criteria is affected by gender (Chan \& Ho, 2000; Luzadis et al., 2008). Gender has been and seems to be one of the most common forms of segmentation used in various areas. Gender refers to the societal meaning given 
to male and female categories (Wood \& Eagly, 2002). According to Newman (2018), gender is a non-physiological aspect of sex; the cultural expectations toward femininity (female sex type) and masculinity (male sex type). Even though in recent years women's feminine traits declined significantly (Donnelly \& Twenge, 2017), men remain to be masculine and women tend to be feminine.

The strongest influence of employment choice by gender includes several career goals: working for a company with a strong reputation, the opportunity to work with thought leaders, being rewarded for good performance, working for a company that has a culture of innovation. Selcuk \& Cevikcan (2011) mentioned that although the rank of the career goals criteria does not vary between gender, the importance degrees are perceived differently by male and female students. Other researches conducted by Beneria (2001), Setiawati \& Zulkaida (2007), Selcuk \& Cevikcan (2011), and Wiswall \& Zafar (2018) also suggested preferential differences based on gender.

A research conducted by Grubb et al. (2006) suggests that female students are particularly concerned with compensation and fringe benefits, job security, and long-term career opportunities among other career goals or job factors. In addition to those factors, a male is also attracted to working conditions, involvement with decision making, and marketability. Further, it is found that a friendly work environment is more appealing to females compared to males (WHO, 2011). Moreover, although overall women are inclined towards family life, traditional patriarchy has been weakened by the necessity of families and has accepted an increased contribution by young women (Hancock, 2001). This is also supported by Bahramitash (2002) with a particular case of Indonesia. Thus, based on the arguments presented, hypothesis 1 is developed.

H1: Gender influences the relative importance of career goals. Female and male differ in their preferences on career goals.

Potential employees will often turn to a reference group when choosing between several acceptable employers to which they may apply for. When an employee has a family, particularly with children, a female employee will need a position with more flexibility, but still offer good remuneration. On the other hand, a male employee might lean towards remuneration more than flexibility (Maroko \& Uncles, 2009).

Moreover, Maroko \& Uncles (2009) argue that the immediate reference group an applicant turns to when choosing between several employers is family. Moreover, in a collectivist society like Indonesia, a family is also one of the primary deciding factors, and therefore should be taken into account (Hofstede et al., 2010). In this context, two major groups can be made: single and married or have been married. Since people who have been divorced or widowed are most likely to maintain their decision-making process in their post-marital circumstances (Madden-Derdich \& Leonard, 2002), there is no distinction made between married and have been married (divorced and widowed).

Wong et al. (1999) found that unmarried people prefer to spend their time to achieve development in their career. In contrast, married people prioritize balance between work and family. Similarly, Carvalho and Silva (2018) showed that the unmarried people are more interested in career development and financial benefits than the married group. Accordingly, hypothesis 2 is obtained as follows.

H2: Marital status affects the relative importance of career goals. Single and married differ in their preferences on career goals.

Although selection based on the Grade Point Average (GPA) is often questioned for equity, it is still common to use GPA to predict success in job performances, particularly for fresh graduates (APS, 2013; Atkins \& Kent, 1988; Gudmundsson, 2020; Idris, 2020). A higher GPA represents higher competencies and reflects better cognitive ability or other important psychological characteristics (Sulastri et al., 2015).

In relation to educational background, the need for achievement might show an individual's desire to achieve personal performance. A study in nine European countries suggests that students with a high need for achievement tend to place more emphasis on employer reputation when 
choosing an employer (Caligiuri et al., 2010). Getting hired by successful companies which signifies one's superior competence over one's peers is an important goal for high achievers and fulfill their need for achievement. Gandossy \& Kao (2004) also suggest that high potentials are motivated by opportunities for development as well as performance-based rewards. Recent research by Anita \& Mandhavkumar (2012), and Bellou et al. (2018) showed similar findings. In this research, high achievers or high potentials are represented by high GPA. Hypothesis 3 is developed based on the presented arguments.

H3: GPA affects career goals choice. Students with different ranges of GPA have a distinct preference on their career goals.

Socioeconomic background may have an impact on career goals. Research done by Leitao et al. (2013) showed that people with lower income prefer to have a career that results in quicker returns and small investment. On the contrary, higher-income subjects tend to find careers or jobs that are more challenging. Similar arguments are presented by Sheehy-Skeffington \& Rea (2017). People with lower income tend to choose career goals characterized by low risk. They also value stability, avoid change, conform to traditional norms. Based on the arguments mentioned, the economic background may affect career goals. Then, hypothesis 4 is developed.

H4: Economics background influences the relative importance of career goals. Students with different income levels prefer to have different career goals.

In applying for jobs, potential employees are also self-screening themselves to match the requirements. Work experience is one of the most frequently used factors to classify applicants (Pollard et al., 2015) and thus, also affects how a person perceived an employer brand (Maroko \& Uncles, 2009).

According to the social learning theory of career decision-making (Orahood et al., 2004), working experience may influence a career path or another. Thus, experience (direct or indirect) people got from previous employment will generate expectations concerning opportunity and success, subsequently influence career intention (Knight et al., 2006).

Working experiences provide people opportunities to involve in many activities. Satisfaction or dissatisfaction in attending organizational activities, achieving performances, interacting with people, may affect people in setting expectations or targets. Consequently, the experiences will affect people in establishing realistic career goals. People with more experiences may have better knowledge, skills, and networks. As a result, they are more likely to have high selfesteem, perceived competencies, and a need for achievement. They will seek jobs with high responsibility, challenges, or opportunities to express their competencies. This situation will result in differences from people with less working experiences. Therefore, hypothesis 5 is proposed.

H5: Working experiences influence career goals choice. People with more working experiences differ in their preferences on career goals compare to those with less working experiences.

\section{Methods}

\section{Research Framework and Design}

In the view of the theories above-mentioned, it is realized that there are several theories pertinent to the study. The study takes into account the employer brand theory by reversing the process from "what it feels like to work for the organization" to "what kind of organization would students like to work for" (Mandhanya \& Shah, 2010). This study uses the value propositions of employer brand (Barrow \& Mosley, 2005) which are incorporated in the attractiveness dimensions (Caligiuri et al., 2010) as well as the individual career goals to match what the company offers and measures itself against potential employee with how the future employees prioritize their expectations and needs (Berthon et al., 2005; Kalinowski, 2005).

The study aims to meet the needs of the organization and the individual (Garrow \& Hirsh, 2008). The study also directed to address uncertainty on the demand side: how to balance makeversus-buy decisions and how to reduce the risks in forecasting the demand for talent (Cappelli, 
2008). Therefore, different preferences of career goals due to the different characteristics were observed to address the need of a systematic attraction, identification, development, engagement/retention, and deployment of those individuals with high potential who are of particular value to an organization (Garrow \& Hirsh, 2008).

In conducting the study, researchers adapted the research models from Berthon et al. (2005), Tuzuner and Yuksel (2009), and Universum (2005) that examined the employer branding concept and employer attractiveness as a component of internal marketing. The concepts that were used are similar to Alnıaçık \& Alnıaçık (2012).

The research design consisted of two major parts: the evaluation of characteristics attractiveness, and individual career goals. The study utilized a questionnaire aimed to map the key characteristics of an ideal employer based on gender, marital status, academic achievements, economic background, and working experience of the Indonesian graduate business school students.

\section{Participants and Procedures in Collecting Data}

The context of this research is the graduate business school students. This study included all regular students who were still active within the period of the data gathering. The sample obtained from the population was 150 students. On the basis that there is specific information needed, only students interested to get employment were included in the sample.

The data for this study were obtained directly from the respondents using a selfadministered questionnaire. The questionnaires were distributed and collected after classes to students in classes, discussion rooms, and the library by researchers. All respondents completed the questionnaires anonymously and were assured that the information they provided would remain confidential and be used only for the purpose of this research. One-hundred-and fifty-five questionnaires were distributed with an overall response rate of $94 \%$. There were six questionnaires returned with incomplete responses and three questionnaires returned with incomplete respondents' profiles. Therefore, incomplete questionnaires were not included in the study.

\section{Measurement and Scale}

To clarify the concepts or variables measured and to avoid misinterpretations in observations and measurements, the followings are several operational definitions for the variable specifically used in this study. The attractiveness characteristics for the employer brand variable were derived from Berthon et al. (2005) dimensions of attractiveness that correspond with Universum's drivers of employer attractiveness (Universum, 2011). The dimensions are as follows: (1) Reputation and Image (Universum, 2011) or Interest Value (Berthon et al., 2005): the extent to which an individual is attracted to an employer due to its exciting work environment, novel work practices, and highquality, innovative products and services. It is the attributes of the employer as an organization. (2) People and Culture (Universum, 2011) or Social Value (Berthon et al., 2005): the extent to which an individual is attracted to an employer due to its working environment that is fun, happy, provides good collegial relationships and a team atmosphere. It is the social environment and attributes of the workplace. (3) Remuneration and Advancement Opportunity (Universum, 2011) or Economic Value (Berthon et al., 2005). This dimension explains whether an individual is attracted to an employer due to its above-average salary and compensation package, job security, and promotional opportunities. It is the monetary compensation and other benefits. (4) Job Characteristics (Universum, 2011) or Development and Application Value (Berthon et al., 2005). This dimension describes whether an individual is attracted to an employer because it provides recognition, careerenhancing experience, self-worth, and confidence, together with the opportunity to apply what they have learned and to teach others. It is the contents and demands of the job including the learning opportunities.

These operational definitions for attractiveness dimensions were used and measured through twelve career goal items as shown in Table 1. The career goal items were derived from Berthon et al. (2005) and Universum's top ten career goals (Universum, 2011) which were then evaluated based on their appropriateness with Indonesian environments. 
Table 1. Variables in questionnaire

\begin{tabular}{clc}
\hline Variable & \multicolumn{1}{c}{ Attractiveness dimensions/characteristics } & Number of career goals \\
\hline \multirow{4}{*}{ Employer brand } & 3 \\
& People and culture & 3 \\
& Remuneration and advancement & 3 \\
& Reputation and image & 3 \\
\hline & Job characteristics & 12 \\
\hline
\end{tabular}

The original scales in the survey instrument (Berthon et al., 2005; Universum, 2011) were adjusted to accommodate cultural differentials (Hofstede et al., 2010; Trompenaars \& HampdenTurner, 1998). Items on the Likert-type 5-point scale are modified to minimize neutrality or central tendency bias. According to Trompenaars and Hampden-Turnuer (1998), Indonesia is classified as a country high in the neutrality dimension. To prevent participants from choosing the middle point (i.e."neutral"), the middle option is removed. Then, a six-point Likert-like scale ranging from "very unimportant" (1) to "very important" (6) was used. The respondents were asked to indicate their positions on the degree of importance towards each of the twelve questions regarding the career goals of the employer brand attractiveness characteristics (three questions for each of the four characteristics).

\section{Classification of GPA, Economic Background, and Working Experiences}

In this study, GPA was classified into 3 categories: good (3.00 - 3.24), very good (3.25 - 3.50), and excellent $(3.50-4.00)$. This categorization was rather arbitrary. However, similar categorization was practiced in Indonesian or Malaysian universities in Indonesia.

One of the common practices to determine economic background is the evaluation of household expenditures (Husein, 2000). Although it is debatable whether or not the measure is valid, this technique still provides insight on determining a person's economic background. Using a baseline introduced by Thomas, et al. (1999) and taking into account the inflation rates to adjust the expenditure, there are four major monthly expenditure groups: below 1 million rupiahs (low level), between 1 to 2.5 million rupiahs (middle-low), between 2.51 to 5 million rupiahs (middlehigh), and above 5 million rupiahs (high).

In the case of Indonesia, several distinctions were made by the recruiters to determine the level of opening of an applicant based on working experience: fresh graduate (no work experience), entry level (experience below 2 years), junior level (experience between 3 to 5 years), and senior level (experience above 5 years). Although the length of experience does not necessarily portray one's position in a company, it is also a critical determinant when perceiving an employer brand.

\section{Validity and Reliability Test}

The English version of the questionnaire was translated into the Indonesian language using backtranslation procedures (Chapman \& Carter, 1979). This step aimed to adapt the questionnaire into the Indonesian work and cultural context (Souza et al., 2017). After having back translation, face validity was performed to check the relevance of the items in measuring variables in the context (Beugelsdijk \& Welzel, 2018) based on the perception of respondents. Face validity is also important to identify whether the questions are easily understood and also practical (Connell et al., 2018; Nevo, 1985). Fifteen students that had similar characteristics to the target sample were involved in this step. The revision was made due to typos and to make several questions more understandable.

The next process is validating the measurement using statistical analysis and structural equation modeling (SEM). The tests were done using SPSS and IBM SPSS AMOS. To test the validity of the construct, a confirmatory factor analysis through structural equation modeling was done in AMOS. Besides the initially proposed model, two alternative models were also developed and evaluated based on the model fit criteria. The model that scored the highest is the alternative model that consists of a second-order four-factor structure. It specifically comprises four latent 
dimensions: Job Characteristics (JC), Employer Reputation and Image (ERI), Remuneration and Advancement Opportunities (RAO), and People and Culture (PC); with the observed items significantly loading according to the proposed pattern.

There are a number of tests and fit indices that can be used to examine whether the model fits the observed data: first is the chi-square divided by the degree of freedom where $<5$ is deemed appropriate, second is the root mean residual (RMR) where $<0.10$ is advised, the goodness of fit index (GFI) where $>0.90$ is predetermined, adjusted goodness of fit index (AGFI) where $>0.800$ is preferred, and the root mean square error of approximation (RMSEA) with value $<0.07$ is favored. In this research, the CMIN/df was 1.744, while the RMR was 0.032, GFI was 0.914, AGFI was 0.866 , and RMSEA was 0.072 .

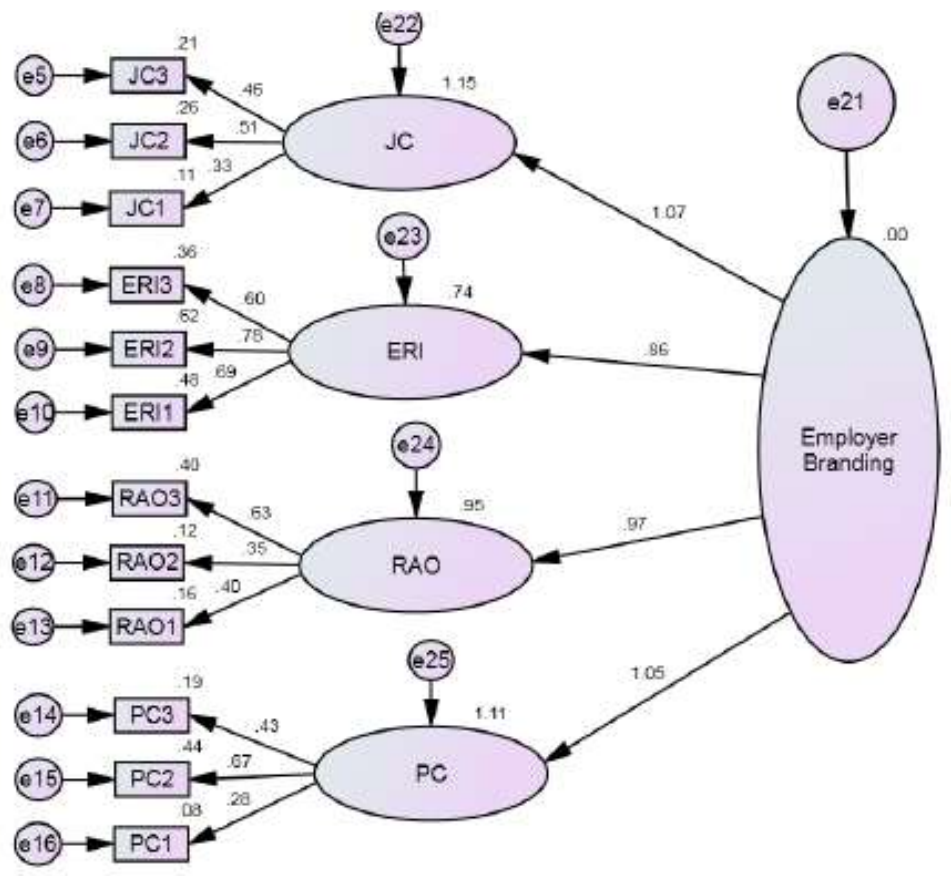

Figure 1. Item loadings for second-order and four-factor model

Factor loadings of career goals were presented in Figure 1 and Table 2. The figure and the table showed that the highest factor loading was 0.78 (ERI2), and the lowest was 0.28 (JC3). In terms of the dimensions of job attractiveness, ERI presented the highest factor loading. On the contrary, PC showed the lowest among other dimensions.

Table 2. Factor loading of career goals

\begin{tabular}{lllllllllllll}
\hline Item & PC1 & PC2 & PC3 & ERI1 & ERI2 & ERI3 & ROA1 & ROA2 & ROA3 & JC1 & JC2 & JC3 \\
\hline Loding factor & 0.46 & 0.51 & 0.33 & 0.60 & 0.78 & 0.69 & 0.63 & 0.35 & 0.40 & 0.43 & 0.67 & 0.28 \\
\hline
\end{tabular}

A reliability test using Cronbach's alpha was utilized to examine the questionnaire item. The closer the coefficient of alpha is to 1, the higher the internal consistency. In this research, an alpha coefficient of 0.805 was achieved. The reliability between item and construct was also assessed by using corrected item-total correlation (Table 3). The score can't be too low to include in further analysis (Wieland et al., 2017).

In general, items presented in Table 1 and Figure 1 are valid and reliable. However, several items in Figure $1(\mathrm{JC1}=0,33, \mathrm{RAO} 2=0,35, \mathrm{PC} 1=0,28)$ showed low factor loadings, those were below the lowest acceptable threshold or 0,40 (Matsunaga, 2010). In relation to item-total correlation, PC1 presented a score of 0,268 , which is lower than the lowest acceptable cut-off point 0,30 (Cristobal et al., 2007). However, those items are retained for subsequent analysis in order to keep the measurement properties (Wieland et al., 2017). Keeping not-valid questions is also common in doing research (Mitchell et al., 2001; Wieland et al., 2017). 
Table 3. Reliability test of career goals

\begin{tabular}{ccc}
\hline Item & $\begin{array}{c}\text { Corrected item-total } \\
\text { correlation }\end{array}$ & $\begin{array}{c}\text { Cronbach's Alpha if } \\
\text { item deleted }\end{array}$ \\
\hline JC1 & 0.346 & 0.801 \\
JC2 & 0.485 & 0.789 \\
JC3 & 0.429 & 0.793 \\
RAO1 & 0.342 & 0.800 \\
RAO2 & 0.311 & 0.802 \\
RAO3 & 0.552 & 0.781 \\
ERI1 & 0.568 & 0.779 \\
ERI2 & 0.604 & 0.775 \\
ERI3 & 0.512 & 0.785 \\
PC1 & 0.268 & 0.807 \\
PC2 & 0.586 & 0.780 \\
PC3 & 0.408 & 0.795 \\
\hline
\end{tabular}

\section{Method to Analyze Data}

After the data had been gathered, compiled, and categorized; there were several techniques employed to analyze and make use of each collected data. The data was ordered based on the characteristics' relative importance and assigned points accordingly (the first rank is scored the highest $=6$ ). The data were then analyzed using a K-related samples test and weighted-mean average computation with ANOVA tables. The data was also analyzed using a K-independent samples test and a One-Way ANOVA test to identify the differences of career goal preferences based on demographic characteristics. This research utilized $95 \%$ confidence level (CL) or p $\leq$ 0.05. Even though it is acceptable to use $90 \%$ confidence level in small sample research or less than 300 (Filho et al., 2013), however, 95\% confidence level is more preferable to increase statistical power in testing hypotheses (Fritz et al., 2012).

\section{Result and Discussion}

\section{Result}

This section was started by presenting important data regarding the respondent's characteristics and career goals. Hypotheses testing was carried out following the discussion of the descriptive statistics.

\section{Descriptive Statistics}

This research utilized scores from 1 (very unimportant) to 6 (very important). In general, the response is classified as important and very important. It indicated that companies need to include those career goals in their employer branding to attract talented candidates. Specifically, Table 4 showed that the highest mean was 5.55 (JC2) and the lowest one was 4.89 (JC3). JC2 reflects organizational aspects related to a variety of tasks and challenges. Respondents put the most important career goal on the characteristic. This finding did not support research by Reis and Braga (2016) that found career goals related to challenging tasks and creative working environment (interest values) were ranked fourth. However, Reis and Braga found similar results regarding remuneration and benefits (RAO1 and RAO2). These career goals were ranked second after interest values.

Career goals based on the respondent's characteristics were presented in Table 5. The lowest score was 4.70 (JC3 for high economic status) and the highest one was 5.71 (PC3 for respondents with $3.00-3.24$ GPA). Based on the scale (1 to 6), the scores, in general, were categorized as important and very important. 
Table 4. Means of career goals

\begin{tabular}{lcc}
\hline Career goals item & Mean & Std. Deviation \\
\hline PC1 & 5.41 & 0.681 \\
PC2 & 5.42 & 0.652 \\
PC3 & 5.49 & 0.613 \\
RAO1 & 5.41 & 0.692 \\
RAO2 & 5.51 & 0.613 \\
RAO3 & 5.07 & 0.828 \\
ERI1 & 5.32 & 0.761 \\
ERI2 & 5.15 & 0.800 \\
ERI3 & 5.00 & 0.814 \\
JC1 & 5.33 & 0.753 \\
JC2 & 5.55 & 0.588 \\
JC3 & 4.89 & 0.762 \\
\hline
\end{tabular}

Table 5. Means differences of career goals based on employee characteristics

\begin{tabular}{|c|c|c|c|c|c|c|c|c|c|c|c|c|c|}
\hline & Freq. & PC1 & PC2 & PC3 & $\begin{array}{c}\text { RAO } \\
1 \\
\end{array}$ & $\begin{array}{c}\text { RAO } \\
2 \\
\end{array}$ & $\begin{array}{c}\text { RAO } \\
3 \\
\end{array}$ & ERI1 & ERI2 & ERI3 & JC1 & JC2 & JC3 \\
\hline \multicolumn{14}{|l|}{ Gender } \\
\hline Male & 85 & 5.33 & 5.36 & 5.47 & 5.35 & 5.55 & 4.96 & 5.32 & 5.04 & 4.86 & 5.21 & 5.56 & 4.81 \\
\hline Female & 61 & 5.52 & 5.51 & 5.51 & 5.49 & 5.44 & 5.21 & 5.33 & 5.31 & 5.20 & 5.49 & 5.52 & 5.00 \\
\hline Sig. & & 0.088 & 0.191 & 0.716 & 0.233 & 0.285 & 0.074 & 0.936 & 0.039 & 0.013 & 0.026 & 0.686 & 0.142 \\
\hline \multicolumn{14}{|c|}{ ser } \\
\hline$<26$ years & 84 & 5.39 & 5.40 & 5.48 & 5.40 & 5.48 & 5.12 & 5.27 & 5.14 & 4.96 & 5.29 & 5.64 & 4.90 \\
\hline $26-29$ & 26 & 5.46 & 5.50 & 5.58 & 5.27 & 5.54 & 4.96 & 5.27 & 5.12 & 5.08 & 5.35 & 5.31 & 4.96 \\
\hline$>29$ years & 36 & 5.42 & 5.42 & 5.44 & 5.53 & 5.56 & 5.03 & 5.47 & 5.19 & 5.03 & 5.42 & 5.50 & 4.81 \\
\hline Sig. & & 0.904 & 0.808 & 0.687 & 0.348 & 0.779 & 0.662 & 0.396 & 0.921 & 0.806 & 0.680 & 0.033 & 0.707 \\
\hline \multicolumn{14}{|l|}{ Marital status } \\
\hline Single & 109 & 5.35 & 5.41 & 5.46 & 5.36 & 5.49 & 5.05 & 5.28 & 5.11 & 4.98 & 5.30 & 5.54 & 4.88 \\
\hline Marri & 37 & 5.59 & 5.46 & 5.57 & 5.57 & 5.57 & 5.14 & 5.43 & 5.27 & 5.05 & 5.41 & 5.57 & 4.92 \\
\hline Sig. & & 058 & 0.709 & 0.3 & 0.111 & 0.488 & 0.573 & 0.308 & 0.294 & 0.642 & 0.476 & 0.815 & 0.793 \\
\hline \multicolumn{14}{|l|}{ GPA } \\
\hline $3.00-3$ & 24 & 5.38 & 5.63 & $5.71 \mathrm{~b}$ & 5.42 & 5.54 & 5.04 & 5.42 & 5.25 & 5.08 & 5.54 & 5.63 & 5.04 \\
\hline 3.25 & 49 & 5.41 & 5.41 & 5.61 & 5.31 & 5.59 & 5.31 & 5.45 & 35 & 5.14 & 5.41 & 5.61 & 4.88 \\
\hline $3.50-4.00$ & 73 & 5.42 & 5.37 & 5.33 & 5.48 & 5.44 & 4.92 & 5.21 & 4.99 & 4.88 & 5.21 & 5.48 & 4.85 \\
\hline Sig. & & 0.953 & 0.247 & 0.006 & 0.400 & 0.384 & 0.038 & 0.179 & 0.039 & 0.180 & 0.109 & 0.373 & 0.560 \\
\hline \multicolumn{14}{|l|}{$\begin{array}{l}\text { Working } \\
\text { experiences }\end{array}$} \\
\hline Never & 58 & 5.28 & 5.31 & 5.38 & 5.38 & 5.43 & 5.05 & 5.28 & 5.10 & 4.84 & 5.33 & 5.60 & 4.95 \\
\hline$<2 y$ & 42 & 5.57 & 5.55 & 5.60 & 5.43 & 5.60 & 5.14 & 5.26 & 5.19 & 5.17 & 5.31 & 5.57 & 4.81 \\
\hline $3-5$ years & 10 & 5.60 & 5.50 & 5.70 & 5.10 & 5.40 & 4.80 & 5.40 & 5.00 & 5.00 & 5.00 & 5.20 & 5.20 \\
\hline$>5$ years & 36 & 5.39 & 5.44 & 5.47 & 5.53 & 5.56 & 5.08 & 5.44 & 5.22 & 5.06 & 5.44 & 5.53 & 4.81 \\
\hline & & 0.143 & 0.331 & 0.229 & 0.365 & 0.518 & 0.703 & 0.683 & 0.817 & 0.259 & 0.320 & 0.250 & 0.410 \\
\hline \multicolumn{14}{|c|}{ Economic status } \\
\hline Low & 13 & 5.08 & 5.62 & 5.54 & 5.31 & 5.54 & 5.08 & 5.31 & 5.23 & 5.15 & 5.23 & 5.46 & 5.31 \\
\hline Mid. L & 11 & 5.55 & 5.45 & 5.64 & 5.55 & 5.45 & 5.18 & $5.1\}$ & 5.27 & 4.91 & 5.45 & 5.55 & 5.00 \\
\hline Mid. High & 95 & 5.48 & 5.42 & 5.47 & 5.35 & 5.49 & 5.12 & 5.33 & 5.20 & 5.01 & 5.39 & 5.58 & 4.87 \\
\hline High & 27 & 5.26 & 5.33 & 5.44 & 5.63 & 5.56 & 4.85 & 5.37 & 4.89 & 4.93 & 5.11 & 5.48 & $4.70 \mathrm{a}$ \\
\hline Sig. & & 0.111 & 0.649 & 0.824 & 0.241 & 0.957 & 0.504 & 0.923 & 0.305 & 0.842 & 0.336 & 0.831 & 0.121 \\
\hline
\end{tabular}

Note: $\mathrm{a}=$ the lowest score, $\mathrm{b}=$ the highest score.

\section{Analysis and Findings on Career Goals Items of The Dimensions}

As seen in the measurement model (Figure 1), the employer brand's attractiveness dimensions are reflected by various career goal items that have individual standpoints. Therefore, an analysis on each of the career goal items of the employer brand attractiveness dimensions as well as their differences based on the respondents' characteristics is needed.

Before analyzing the differences based on respondents' characteristics, this research examined the general preferences of respondents on career goals. A weighted-mean average divided 
by the maximum score of importance was computed to obtain the percentages of the career goal items over overall importance as depicted in Figure 2. For example, career goal item PC1 (job aspect that will enable me to have a good work/life balance) indicated a weighted-mean average of 5.41 from the maximum score of 6.00. The percentage of PC1 career goal was 5.41:6.00 X 100\% $=90.1667 \%$ or $90.2 \%$. Using SPSS 15.0 version, a K-related samples test, the Friedman Test, was then used to examine the overall outlook of how the students perceive the importance of each career goal item which reflected the employer brand attractiveness dimensions.

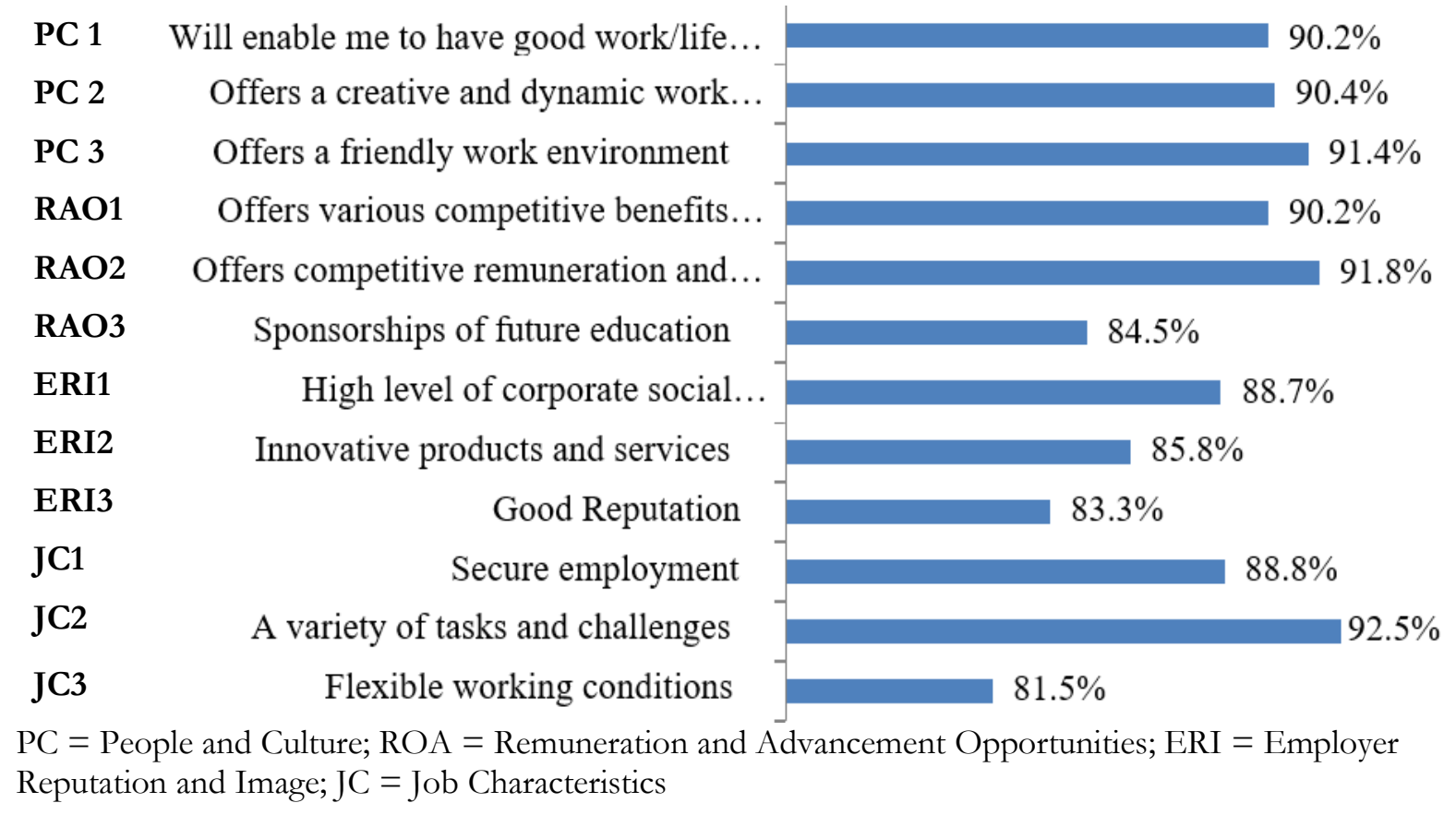

Figure 2. Preference on career goals

Based on the statistic test, the Chi-Square value was 166.246 with the degree of freedom of 11 and asymptotic significance of 0.000 . Thus, it can be concluded that the career goal items were seen as having a different degree of importance by the students. Statistical tests using One-Way ANOVA were performed to confirm each item's mean differences based on each characteristic group such as gender, marital status, academic achievement, work experiences, and economic status.

Table 6. Summary of One-Way ANOVA based on Respondents' Characteristics

\begin{tabular}{lccccc}
\hline Career Goals & Gender & Marital status & GPA & Work experiences & Economic background \\
\hline PC1 & $0.088^{*}$ & $0.058^{*}$ & 0.953 & 0.143 & 0.111 \\
PC2 & 0.191 & 0.709 & 0.247 & 0.331 & 0.649 \\
PC3 & 0.716 & 0.352 & $0.006^{* *}$ & 0.229 & 0.824 \\
RAO1 & 0.233 & 0.111 & 0.400 & 0.365 & 0.241 \\
RAO2 & 0.285 & 0.488 & 0.384 & 0.518 & 0.957 \\
RAO3 & $0.074^{*}$ & 0.573 & $0.038^{* *}$ & 0.703 & 0.504 \\
ERI1 & 0.936 & 0.308 & 0.179 & 0.683 & 0.923 \\
ERI2 & $0.039^{* *}$ & 0.294 & $0.039^{* *}$ & 0.817 & 0.305 \\
ERI3 & $0.013^{* *}$ & 0.642 & 0.180 & 0.259 & 0.842 \\
JC1 & $0.026^{* *}$ & 0.476 & 0.109 & 0.430 & 0.336 \\
JC2 & 0.686 & 0.815 & 0.373 & 0.250 & 0.831 \\
JC3 & 0.142 & 0.793 & 0.560 & 0.410 & 0.121 \\
\hline NC: & & & & &
\end{tabular}

Note: $*=$ significant at $\mathrm{p} \leq 0.10,{ }^{* *}=$ significant at $\mathrm{p} \leq 0.05$.

From the ANOVA results, it can be concluded that differences in career goals only occur on gender and GPA. The most frequently significant item was ERI2. A significant difference 
occurred in gender and GPA. Therefore, Hypothesis 1 and Hypothesis 3 were supported. On the other hand, Hypotheses 2, 4, and 5 were not supported. The summary of the significant values for the one-way ANOVA test is shown in Table 6. The significant items, $\mathrm{p} \leq 0.05$, are highlighted. Several career goal differences (PC1 and RAO3) were significant at $\mathrm{p} \leq 0.10$.

\section{Discussion}

The findings for career goals items were generally consistent with the known theories of organizational attraction. An organization with a variety of tasks and challenges (JC2) was the most attractive. Competitive remuneration and benefits (ROA2 and ROA3), supportive work environment, challenging and interesting work (PC1, PC2, PC3) were also recognized as important or very important and predictive of attraction. Previous studies of job attributes or career goals that lead to job choice indicated that type of work, advancement opportunities, and coworkers are also essential for the job seekers (Turban et al., 1993). However, although previous studies had shown that organizational image can positively influence organizational attraction (Ana \& Dubravka, 2018; Gatewood et al., 1993) and that corporate social performances (ERI1 and ERI3) were an important part of organizational reputation and may affect organizational attraction (Backhaus et al., 2002; Greening \& Turban, 2000), it is generally not the case in the Indonesian students. The students are least seeking the flexible working conditions (JC3) and the company reputation (ERI3). The results of all Kruskal-Wallis $\mathrm{H}$ Test for each respondent characteristics show existing differences for various career goal items among the groups and the ANOVA tests performed after confirming the differences.

Due to various reasons, men and women have different career goals when it comes to getting a job. In the case of Indonesian students, the result shows that a company that offers innovative products and services (ERI1), and reputation (ERI2) were significantly more important to women rather than to men. Another significant difference was also found in the attraction to secure employment (JC1) which showed higher means for women.

According to Backhaus and Tickoo (2004), individuals may be attracted to organizations that they perceive as large, well-known, and prestigious because as members of such organizations they feel they can also gain credibility and prestige. This explains why women who have a long history of becoming second-class citizens due to gender-based, socially constructed inference (Joekes, 1995) are attracted to the company's good reputation and innovative products and services. Previous research by Chow and Ngo (2011), Virtanen et al. (2003), and Wiswall and Zafar (2018) explains women's attraction to secure employment; they found that changes from the low-security job to high-security job was more often offered to men than to women. In addition, the possibilities for women to be employed in continuous process industries are often limited and there is a more relative docility for dismissal and poor treatment to women (Joekes, 1995; Zwiech, 2009).

Although showing no significant difference at $95 \%$ confidence level, there is a difference in career goals between marital status groups at $90 \%$ confidence level. Work-life balance is perceived to be significantly important for those who are married or have been married. Increased demands on the job and at home call for harmony between managing work and family life. This is consistent with the results of previous researches that suggest the need of individuals to integrate and overlap work and family responsibilities (Greenhaus et al., 2003; Hill et al., 2001; Tausig \& Fenwick, 2001).

There are several career goals which show significant differences among academics achiever achievement groups. Motivated by a sense of high achievement, the top achievers (GPA above 3.50) are used to involved in a competitive and challenging environment (Shipley et al., 2010). Therefore, a friendly work environment is less desirable for them and their needs to excel in work, and increase their managerial skills also seem to be above their expectations for the company's sponsorship of future education (Maes et al., 1997). In addition, a company's reputation for its innovative products and services is also at the bottom of their list. On the contrary, those who achieved a lower GPA (between 3.00-3.24) expect to find a friendly work environment while those who achieved GPA between 3.25-3.49 favor sponsorship for future education as well as innovative products and services.

Although there are no significances at both $95 \%$ and $90 \%$ confidence level for both work experiences and economic background, the result for career goals could assist us in identifying the 
significant items for each dimension among the groups. The work-life balance has the most significant difference among work experience groups. Those who have worked demand a higher work-life balance compared to those who have never worked. However, for the senior staff with more-than-five-year experience, the desire for work-life balance is decreasing. Presumably, this is because those who have never worked yet are categorized as young and single, thus they did not see the needs yet to balance their work and life. On the other hand, those who have five-year experience are already in a settled position both within the company and their family life.

Similarly, although most likely for different reasons, the work-life balances also have the highest significant difference among economic background groups. Students who are from middlelow and middle-high economic backgrounds have a higher desire for work-life balance compared to those from low and high economic backgrounds. This might suggest how the students shape their expectations from their experience in their family and lifestyle (Perrons, 2003; White et al., 2003) in relation to their working- hours. Moreover, the small differences between means for competitive remuneration and salary among the economic groups may imply the current condition in Indonesia. Students from middle-high and high economic backgrounds are motivated to maintain their standard of living while those from low and middle-low economic backgrounds are triggered to improve theirs.

\section{Conclusion}

For organizations to attract and retain prospective employees that fit them, they should understand how they are perceived as an employer to determine what alterations to make in terms of message and communication. Organizations need to recognize what their target group is interested in hearing and through which communication channels the group can be reached. This thesis was designed to extend previous research on employer branding and organizational attraction by examining the attractiveness dimension of employer brand and the career goal items. The main interest was on how variations are revealed by the different characteristics of Indonesian students.

The investigation result on the attractiveness dimensions establishes an initial framework for organizations about where to start building their employer brand when dealing with Indonesian graduate students. Organizations can specifically target their potential employees by managing the dimensions mix based on the empirical finding. However, in further practice consistency or alignment between the employer brand image with the employment experience should be maintained to successfully build the employer brand and promote commitment.

Furthermore, the process of building an employer brand begins with identifying what drives an existing brand: perceptions and beliefs people have about an organization. The perceived career goal items of each dimension contribute to the process by providing a connection between an organization's personality and promise. Career goals address the organization's expectations of their future employees as well as acknowledge the candidates' expectations by offering an attractive benefit. As it links the abstract dimension into a more practical, real-life benefits that a potential employee is seeking may assist in specifying a definite target group.

\section{Implications}

The sample used in this study included graduate business school students who are likely to fill important management positions in their organizations in the near future. Thus, the results of this study have important practical implications for organizations that are looking to attract, recruit and retain key talents. Organizations can tailor their employer brand in line with the findings to create congruence. For example, organizations may consider emphasizing on the attributes that are attractive to high-achievers or to one specific gender. Organizations may also redesign their existing jobs and career paths in line with the preferred values of their future employees target. In summary, this research offered an interesting insight on the relations of employer brand's attractiveness dimensions, career goals, and individual differences.

This research also contributes to the emerging subject related to potential employee's attraction of organizations (Alnıaçık \& Alnıaçık, 2012; K. Backhaus \& Tikoo, 2004; Berthon et al., 
2005; Lievens \& Highhouse, 2003) because it depicts a more detail picture on the various factors that are related on how applicants view a company specifically in the context of Indonesian graduate students. Previous studies were done mostly in the Western countries and more developed countries in Asia (e.g. India and Singapore). Although these data did not necessarily allow generalization beyond its context, the findings reveal how analysis of employer brand characteristics attractiveness as well as its career goal reflections might divulge interesting insights for employer brand utilization in Indonesia. In addition, this study also reveals the need for educational institutions to evaluate and appraise their educational process as well as educational content in order to diversify the graduates' aspirations when entering the job market.

\section{Limitations and Recommendations}

The limitations of this research arise from the nature of the data and of the research. An important issue is that although efforts to minimize and to control systematic common method errors have been prearranged, this study may not be fully resistant to them. The characteristics used were both derived from theory as well as judgment from observations and it may not necessarily be the deciding factors of the students' attraction. For example, it is not possible to conclude from the data to determine which the respondents employment characteristics mechanisms has the greatest impact on conditions that support an employer brand success. The data were also collected from business school students and may not necessarily allow generalization. It is limited in that it may not have captured the reflections of potential employees groups in Indonesia whose characteristics combinations of experience and attitudes toward employer brand differed from the sample used. However, the results of this research may add valuable information regarding specific career goals that are attracted to a group of job seeker.

The process of the data collection in itself may have also caused misrepresentations in the data. The data was gathered regarding the students' attraction to organizations instead of their actual decisions. Being asked to focus on their aspirations may have caused respondents to attribute importance to aspects of expectations too readily rather than taking reality into accounts. Moreover, it should also be noted that the research may not represent a full employer branding research since there might be other influential management or human resources instruments that are not included in this study. While efforts were made to capture some sequential aspects of the process, it was not possible to portray the dynamics of the employer branding process.

Throughout the study, there are several issues that provide opportunities for further investigations. First, there is a need for replications to be made within other students profiles in order to verify if these results maintain its stability among samples with different characteristics. This effort will improve generalizability, and may generate ecological validity (Dawson \& Marcotte, 2017). Second, replications using different research models in the same context may also contribute to the enlargement of the concept. As a way of introducing progress, integrating different theoretical frameworks in this field of research may also be seen as a challenge to enrich the subject. For example, if the career goals for each dimension used in our model were to be substituted with other items that also represent the dimensions, the interpretation of organizational attraction for Indonesian graduate students is likely to be improved.

Moreover, future research may also be conducted by matching the students aspirations with a specific company may help improve the company's current employer brand. Another idea is to conduct a specific brand communication research which may contribute on enlarging the concept of how a company distinguished itself from its similar competitors.

\section{References}

Aldousari, A. A., Robertson, A., Yajid, M. S. A., \& Ahmed, Z. U. (2017). Impact of employer branding on organization's performance. Journal of Transnational Management, 22(3), 153-170.

Alnıaçık, E., \& Alnıaçı, Ü. (2012). Identifying Dimensions of Attractiveness in Employer Branding: Effects of Age, Gender, and Current Employment Status. Procedia - Social and 
Behavioral Sciences, 58, 1336-1343.

Ana, T. V., \& Dubravka, S. Ć. (2018). The relationship between reputation, employer branding and corporate social responsibility. Public Relations Review, 44(4), 444-452.

Anita, J., \& Mandhavkumar, V. (2012). A study on the impact of Personality Characteristics on Employer Attractiveness. Journal of Contemporary Research in Management, 7(3), 11-21.

APS. (2013). The Job Candidate's GPA: There's More Than Meets the 'A.' APS. https://www.psychologicalscience.org/news/minds-business/the-job-candidates-gpatheres-more-than-meets-the-a.html

Atkins, C. P., \& Kent, R. L. (1988). What Do Recruiters Consider Important During the Employment Interview?. Journal of Employment Counseling, 25, 98-103.

Backhaus, K. B., Stone, B. A., \& Heiner, K. (2002). Exploringthe Relationship Between Corporate Social Performance and Employer Attractiveness. Business \& Society, 41(3), 292-318.

Backhaus, K., \& Tikoo, S. (2004). Conceptualizing and researching employer branding. Career Development International, 9(4/5), 501-517.

Badan Pusat Statistik. (2020). Keadaan Ketenagakerjaan Indonesia Februari 2020. In Berita Resmi Statistik.

https://www.bps.go.id/publication/2020/06/19/c0d3df055948f7bcb65890f0/keadaanangkatan-kerja-di-indonesia-februari-2020.html

Bahramitash, R. (2002). Islamic fundamentalism and women's employment in Indonesia. International Journal of Politics, Culture and Society, 16(2), 255-272.

Barron, P., Leask, A., \& Fyall, A. (2014). Engaging the multi-generational workforce in tourism and hospitality. Tourism Review, 69(4), $245-263$.

Barrow, S., \& Mosley, R. (2005). The Employer Brand: Bringing the Best of Brand Management to People at Work. John Wiley \& Sons Ltd.

BCG. (2013). Growing pains, lasting advantage: tackling Indonesia's talent challenges. https://imagesrc.bcg.com/Images/Growing_Pains_Lasting_Advantage_May_2013_tcm9-97662.pdf

Becker, B. E., \& Huselid, M. A. (2006). Strategic human resources management: Where do we go from here? Journal of Management, 32(6), 898-925.

Bellou, V., Stylos, N., \& Rahimi, R. (2018). Predicting hotel attractiveness via personality traits of applicants: The moderating role of self-esteem and work experience. International Journal of Contemporary Hospitality Management, 30(10), 3135-3155.

Benería, L. (2001). Shifting the risk: New employment patterns, informalization, and women's work. International Journal of Politics, Culture and Society, 15(1), 27-53.

Berthon, P., Ewing, M., \& Hah, L. L. (2005). Captivating company: Dimensions of attractiveness in employer branding. International Journal of Advertising, 24, 151-172.

Beugelsdijk, S., \& Welzel, C. (2018). Dimensions and Dynamics of National Culture: Synthesizing Hofstede With Inglehart. Journal of Cross-Cultural Psychology, 49(10), 1469-1505.

Biswas, M., \& Suar, D. (2013). Which Employees' Values Matter Most in the Creation of Employer Branding?. Journal of Marketing Development and Competitiveness, 7(1), 93-102.

Caligiuri, P., Colakoglu, S., Cerdin, J. L., \& Kim, M. S. (2010). Examining cross-cultural and individual differences in predicting employer reputation as a driver of employer attraction. International Journal of Cross Cultural Management, 10(2), 137-151.

Cappelli, P. (2008). Talent management for the twenty-first century. Harvard Business Review, 86(3), $74-81$. 
Carvalho, A., \& Silva, J. (2018). The Work Preferences of Portuguese Millennials - a Survey of University Students. http://repositorium.sdum.uminho.pt/bitstream/1822/60218/1/NIPE_WP_11_2018.pdf

Chan, S. Y., \& Ho, S. S. M. (2000). Desired attributes of public accounting firms in the job selection process: An empirical examination of accounting graduates' perceptions. Accounting Education, 9(4), 315-327.

Chapman, D. W., \& Carter, J. F. (1979). Translation Procedures for the Cross Cultural Use of Measurement Instruments. Educational Evaluation and Policy Analysis, 1(3), 71-78.

Chow, I. H. S., \& Ngo, H. (2011). Gender Differences In Job Attribute Preferences And Job Choice Of University Students In China. Journal of Applied Business Research (JABR), 18(2), $15-25$.

Collins, C. J., \& Stevens, C. K. (2002). The relationship between early recruitment-related activities and the application decisions of new labor-market entrants: A brand equity approach to recruitment. Journal of Applied Psychology, 87(6), 1121-1133.

Connell, J., Carlton, J., Grundy, A., Taylor Buck, E., Keetharuth, A. D., Ricketts, T., Barkham, M., Robotham, D., Rose, D., \& Brazier, J. (2018). The importance of content and face validity in instrument development: lessons learnt from service users when developing the Recovering Quality of Life measure (ReQoL). Quality of Life Research, 27(7), 1893-1902.

Cristobal, E., Flavián, C., \& Guinalíu, M. (2007). Perceived e-service quality (PeSQ): Measurement validation and effects on consumer satisfaction and web site loyalty. Managing Service Quality, 17(3), 317-340.

Daniel, R. G., \& José, N. (2010). Employer Branding Constrains Applicants' Job Seeking Behaviour? Revista de Psicología Del Trabajo y de Las Organizaciones, 26(3), 223-234.

Davies, G. (2008). Employer branding and its influence on managers. European Journal of Marketing, 42(5/6), 667-681.

Dawson, D. R., \& Marcotte, T. D. (2017). Special issue on ecological validity and cognitive assessment. Neuropsychological Rehabilitation, 27(5), 599-602.

Donnelly, K., \& Twenge, J. M. (2017). Masculine and Feminine Traits on the Bem Sex-Role Inventory, 1993-2012: a Cross-Temporal Meta-Analysis. Sex Roles, 76(9), 556-565.

Filho, D. B. F., Paranhos, R., Rocha, E. C. da, Batista, M., Silva Jr., J. A. da, Santos, M. L. W. D., \& Marino, J. G. (2013). When is statistical significance not significant? Brazilian Political Science Review, 7(1), 31-55.

Florea, N. V. (2011). Using Branding to Attract, Reecruit, and Retained Talented Staff. Management and Marketing Journal, 9(2), 283-297.

Fritz, A., Scherndl, T., \& Kühberger, A. (2012). A comprehensive review of reporting practices in psychological journals: Are effect sizes really enough. Theory \& Psychology, 23(1), 98-122.

Gaddam, S. (2008). Modelling Employer Branding Communication: The Softer Aspect of HR Marketing Management. The Icfai Journal of Soft Skills, 2(1), 45-55.

Gandossy, R., \& Kao, T. (2004). Talent Wars $\square$ : Out of Mind , Out of Practice. Human Resource Planning, 27(4), 15-19.

Garrow, V., \& Hirsh, W. (2008). Talent management: Issues off focus and fit. Public Personnel Management, 37(4), 389-402.

Gatewood, R. D., Gowan, M. A., \& Lautenschlager, G. J. (1993). Corporate Image, Recruitment Image and Initial Job Choice Decisions. Academy of Management Journal, 36(2), 414-427.

Ghielen, S. T. S., De Cooman, R., \& Sels, L. (2020). The interacting content and process of the employer brand: person-organization fit and employer brand clarity. European Journal of 
Work and Organizational Psychology, 1-13.

Gholamzadeh, D., \& Jalali, S. (2013). Integrative Approach in Human Resources Strategy Formulation (Case Study: MDN Company). Procedia - Social and Behavioral Sciences, 75, 479487.

Gowan, M. A. (2004). Development of the recruitment value proposition for geocentric staffing. Thunderbird International Business Review, 46(6), 687-708.

Greenhaus, J. H., Collins, K. M., \& Shaw, J. D. (2003). The relation between work-family balance and quality of life. Journal of Vocational Behavior, 63(3), 510-531.

Greening, D. W., \& Turban, D. B. (2000). Corporate Social Performance As a Competitive Advantage in Attracting a Quality Workforce. Business \& Society, 39(3), 254-280.

Grubb, W. L., Harris, M. L., \& MacKenzie, W. I. (2006). Business Students' Perceptions Of Employment In Small And Medium-Sized Enterprises Versus Multinational Corporations: Investigating The Moderating Effects Of Academic Major, Gender, And Personality. Journal of Small Business Strategy, 17(2), 27-35.

Gudmundsson, P. A. (2020, May 15). Does GPA Matter When Job Searching? U.S. News. https://money.usnews.com/money/blogs/outside-voices-careers/articles/does-gpamatter-when-job-searching

Hancock, P. (2001). Rural women earning income in Indonesian factories: The impact on gender relations. Gender and Development, 9(1), 18-24.

Hill, E. J., Hawkins, A. J., Ferris, M., \& Weitzman, M. (2001). Finding an extra day a week: The positive influence of perceived job flexibility on work and family life balance. Family Relations, 50(1), 49-58.

Hofstede, G., Hofstede, G. J., \& Minkov, M. (2010). Cultures and Organizations: Sofware of the mind. In McGraw-Hill (3rd ed.). McGraw-Hill.

Husein, U. (2000). Riset Pemasaran dan Perilaku Konsumen. Gramedia Pustaka Utama.

Idris, M. (2020, March 9). Seberapa penting nilai IPK di mata HRD. Kompas.Com. https://money.kompas.com/read/2020/03/09/073000626/seberapa-penting-nilai-ipkdi-mata-hrd-?page=all\#: :text=Praktisi pengembangan SDM\%2C Audi Lumantoruan,sering dipakai sebagai filter awal.

Ilyas, M. A., Adeel, I., Alshuaibi, A. S. I., \& Shaari, H. (2019). Conceptualizing the relationship between employer brand pride, employer brand reputation, employee engagement and employee brand loyalty. International Journal of Innovation, Creativity and Change, 7(5), 346-361.

Joekes, S. (1995). Trade-related employment for women in industry and services in developing countries. In Occasional Paper - United Nations Research Institute for Social Development, 5.

Johnson, M., \& Roberts, P. (2006). Rules of Attraction: Recruit and Retain the Best Staff with Employer Branding. Marketing Health Services, Spring, 38-40.

Kabarjatim. (2018). Menaker Ungkap 3 Kelemaban Tenaga Kerja Indonesia. https://kabarjatim.com/menaker-ungkap-3-kelemahan-tenaga-kerja-indonesia/

Kalinowski, M. (2005). Employer Branding: Global Best Practices 2005.

Knight, D. K., Crutsinger, C., \& Kim, H. J. (2006). The impact of retail work experience, career expectation, and job satisfaction on retail career intention. Clothing and Textiles Research Journal, 24(1), 1-14.

Leitão, M., Guedes, Á., EmíliaYamamoto, M., \& Lopes, F. de A. (2013). Do people adjust career choices according to socioeconomic conditions? An evolutionary analysis of future discounting. Psychology and Neuroscience, 6(3), 383-390. 
Lievens, F., \& Highhouse, S. (2003). The relation of instrumental and symbolic attributes to a company's attractiveness as an employer. Personnel Psychology, 56(1), 75-102.

Luzadis, R., Wesolowski, M., \& Snavely, B. K. (2008). Understanding criterion choice in hiring decisions from a prescriptive gender bias perspective. Journal of Managerial Issues, 20(4), 468484.

Madden-Derdich, D. A., \& Leonard, S. A. (2002). Shared experiences, unique realities: Formerly married mothers' and fathers' perceptions of parenting and custody after divorce. Family Relations, 51(1), 37-45.

Maes, J. D., Weldy, T. G., \& Icenogle, M. L. (1997). A managerial perspective: Oral communication competency is most important for business students in the workplace. Journal of Business Communication, 34, 67-80.

Mandhanya, Y., \& Shah, M. (2010). employer branding a tool for talent management.pdf. Global Management Review, 4(2), 43-48.

Maroko, L., \& Uncles, M. D. (2009). Employer Branding and Market Segmentation. Journal of Brand Management, 17(3), 181-196.

Matsunaga, M. (2010). How to factor-analyze your data right: do's, don'ts, and how-to's. International Journal of Psychological Research, 3(1), 97-110.

Maurer, R. (2017, October 4). Employer Value Propositions Are Brand Building Blocks. SHRM. https://www.shrm.org/resourcesandtools/hr-topics/talent-acquisition/pages/employervalue-propositions-are-brand-building-blocks.aspx\#: :text=An employer value proposition.,brand strategy for talent acquisition.

Mercer. (2020). Global talent trends 2020. https://workingnation.com/wpcontent/uploads/2020/03/global-talent-trends-2020-report.pdf

Mitchell, T. R., Holtom, B. C., Lee, T. W., Sablynski, C. J., \& Erez, M. (2001). Why people stay: Using job embeddedness to predict voluntary turnover. Academy of Management Journal, 44(6), 1102-1121.

Nevo, B. (1985). FACE VALIDITY REVISITED. Journal of Educational Measurement, 22(4), 287293.

Newman, T. (2018, February 7). Sex and gender: What is the difference? Medical News Today. https://www.medicalnewstoday.com/articles/232363\#gender-identity-and-expression

Orahood, T., Kruze, L., \& Pearson, D. E. (2004). The Impact of Study Abroad on Business Students' Career Goals. Frontiers: The Interdisciplinary Journal of Study Abroad, 10(1), 117-130. https://doi.org/10.36366/ frontiers.v10i1.137

Perrons, D. (2003). The new economy and the work-life balance: Conceptual explorations and a case study of new media. Gender, Work and Organization, 10(1), 65-93.

Pollard, E., Hirsh, W., Williams, M., Buzzeo, J., Marvell, R., Tassinari, A., Bertram, C., Fletcher, L., Artess, J., Redman, J., \& Ball, C. (2015). Understanding Employers' Graduate Recruitment and Selection Practices. In Istitute for Employment Studies (IES). http://publications.aston.ac.uk/id/eprint/29398/1/Employers_graduate_recruitment_an d_selection_practices.pdf

Prahadi, Y. Y. (2016, September). Mau Menangi Perang Talent, Begini Caranya. SWA. https://swa.co.id/swa/trends/management/mau-menangi-perang-talent-begini-caranya

Ranstad. (2019). Employer Brand Research Global Report. https://cdn2.hubspot.net/hubfs/481927/REBR Global report 2019.pdf

Reis, G. G., \& Braga, B. M. (2016). Employer attractiveness from a generational perspective: 
Implications for employer branding. Revista de Administração (São Paulo), 51(1), 103-116.

Sekiguchi, T. (2004). Person-Organization fit and Person-Job fit in employee selection: A review of the literature. Osaka Keidai Ronshu, 54(6), 179-196.

Selçuk, K. H., \& Çevikcan, E. (2011). Job Selection Based on Fuzzy AHP. International Journal of Business and Management., 3(1), 173-182.

Setiawati, D., \& Zulkaida, A. (2007). Perbedaan Komitmen Kerja Berdasarkan Orientasi Peran Gender. Proceeding PESAT, B71-B77. https://adoc.pub/perbedaan-komitmen-kerjaberdasarkan-orientasi-peran-gender-.html

Sheehy-skeffington, J., \& Rea, J. (2017). How poverty affects people's decision-making processes. In Www.Jrf.Org.Uk. https://www.basw.co.uk/system/files/resources/basw_510153_0.pdf

Shipley, N., Jackson, M., \& Segrest, S. (2010). The effects of emotional intelligence, age, work experience, and academic performance. Research in Higher Education Journal, 9, 1-18.

Souza, A. C. de, Alexandre, N. M. C., \& Guirardello, E. de B. (2017). Psychometric properties in instruments evaluation of reliability and validity. Epidemiologia e Serviços de Saúde, 26(3), 649_ 659.

Sulastri, A., Handoko, M., \& Janssens, J. M. A. M. (2015). Grade point average and biographical data in personal resumes: Predictors of finding employment. International Journal of Adolescence and Youth, 20(3), 306-316.

Tanwar, K., \& Kumar, A. (2019). Employer brand, person-organisation fit and employer of choice: Investigating the moderating effect of social media. Personnel Review, 48(3), 799-823.

Tausig, M., \& Fenwick, R. (2001). Unbinding time: Alternate work schedules and work-life balance. Journal of Family and Economic Issues, 22(2), 101-119.

Theurer, C. P., Tumasjan, A., Welpe, I. M., \& Lievens, F. (2018). Employer Branding: A Brand Equity-based Literature Review and Research Agenda. International Journal of Management Reviews, 20(1), 1-25.

Thomas, D., Frankenberg, E., Beegle, K., \& Teruel, G. (1999). Household budgets, household composition and the crisis in Indonesia: Evidence from longitudinal household survey data. In Califronia Center for Population Research On-line Working Paper Series.

Tong, D., \& Waltermann, B. (2013). Growing Pains, Lasting Advantage (Tackling Indonesia's Talent Challenges). The Boston Consulting Group.

Trompenaars, F., \& Hampden-Turner, C. (1998). Riding the waves of culture: understanding cultural diversity in global business (2nd ed.). McGraw-Hill.

Turban, D. B., Eyring, A. R., \& Campion, J. E. (1993). Job attributes: Preferences compared with reasons given for accepting and rejecting job offers. Journal of Occupational and Organizational Psychology, 66(1), 71-81.

Tuzuner, V. L., \& Yuksel, C. A. (2009). Segmenting Potential Employees According to Firm's Employer Attractiveness Dimensions in the Employer Branding Concept. Journal of Academic Research in Economics, 1(1), 46-61.

Twenge, J. M., Campbell, S. M., Hoffman, B. J., \& Lance, C. E. (2010). Generational differences in work values: Leisure and extrinsic values increasing, social and intrinsic values decreasing. Journal of Management, 36(5), 1117-1142.

Universum. https://ww1.prweb.com/prfiles/2011/02/15/4574704/EBInsights2011.pdf

Utomo, W. P. (2019). Indonesia Millennial Report. IDN Research Institute. 
Vijayalakshmi, V., \& Uthayasuriyan, K. (2015). The Impact of Employer Branding on Employee Performance. Indian Journal of Applied Research, 5(8), 211-213.

Virtanen, M., Kivimäki, M., Elovainio, M., Vahtera, J., \& Ferrie, J. E. (2003). From insecure to secure employment: Changes in work, health, health related behaviours, and sickness absence. Occupational and Environmental Medicine, 60(12), 948-953.

White, M., Hill, S., McGovern, P., Mills, C., \& Smeaton, D. (2003). "High-performance" management practices, working hours and work-life balance. British Journal of Industrial Relations, 41(2), 175-196.

WHO. (2011). Building Healthy and Equitable Workplaces for Women and Men: A Resources for Employers and Worker Representatives. https://apps.who.int/iris/bitstream/handle/10665/77350/9789241501736_eng.pdf;jsess ionid=4E9B5970D52EC0992246111205190C10?sequence $=1$

Wieland, A., Durach, C. F., Kembro, J., \& Treiblmaier, H. (2017). Statistical and judgmental criteria for scale purification. Supply Chain Management, 22(4), 321-328.

Wiswall, M., \& Zafar, B. (2018). Preference for the workplace, investment in human capital, and gender. Quarterly Journal of Economics, 133(1), 457-507.

Wong, S., Siu, V., \& Tsang, N. (1999). The impact of demographic factors on Hong Kong hotel employees' choice of job-related motivators. International Journal of Contemporary Hospitality Management, 11(5), 230-242.

Wood, W., \& Eagly, A. H. (2002). A cross-cultural analysis of the behavior of women and men: Implications for the origins of sex differences. Psychological Bulletin, 128(5), 699-727.

Zwiech, P. (2009). Discrimination against women in professional life in chosen pro-feminist theories. Economics and Sociology, 2(1), 96-104. 